\title{
Producing Erosion Risk Map Using Remote Sensing Techniques and RUSLE Method in Halfalı Stream Catchment of Kahramanmaras
}

\author{
Mahmut REIS, Nurşen BOLAT, Hurem DUTAL,Bülent ABIZ* \\ Kahramanmaraş Sütçü İmam University, Faculty of Forestry, Department of Forestry Engineering \\ Kahramanmaraş/Turkey \\ Received Date: 26.01.2017 Corresponding author: bulentabis@ gmail.com \\ Accepted Date: 3.03.2017
}

\begin{abstract}
In this study, it is aimed to determine the potential erosion risk condition of the area using remote sensing techniques and RUSLE method in Halfal 1 Stream Catchment, which is $25 \mathrm{~km}$ away from Kahramanmaras province. With the purpose of applying this method, rainfall erosivitiy index (R) has been generated by means of modified fournier index (MFI). Soil erodibility factor (K) has been produced using Inverse Distance Weighted technique and soil sample obtained from study area. Slope length and slope steepness factor (LS) has been created by the help of digital terrain elevation model. Vegetation management factor $(\mathrm{C})$ has been generated using remote sensing techniques. Whole factors obtained have been overlapped in Geographic Information System (GIS) and soil loss belonging to study area has been determined using raster calculator command within map algebra module. Erosion risk map has been produced, and has been divided into 5 classes. According to potential erosion risk map obtained, $60.35 \%$ of area has been subject to very low erosion risk, while $2.60 \%, 6.08 \%, 10.37 \%$ and $20.60 \%$ has been subject to low, medium, high and very high erosion risk, respectively.
\end{abstract}

Keywords: RUSLE, soil erosion, GIS, remote sensing

\section{Kahramanmaraş Halfalı Deresi Yağış Havzasında Uzaktan Algılama Teknikleri ve RUSLE} Yöntemi Kullanılarak Erozyon Risk Haritasının Oluşturulması

Özet: Bu çalışma ile Kahramanmaraş ili merkezine $25 \mathrm{~km}$ uzaklıkta bulunan Halfalı Deresi Yağış Havzasında Uzaktan algılama Teknikleri ve RUSLE (Revised Universal Soil Loss Equation) yöntemi kullanılarak alanın potansiyel erozyon risk durumunun belirlenmesi amaçlanmıştır. Yöntemin uygulanması amacıyla yağmurun erozivite indeksi (R), modifiye fournier indeksi (MFI) yardımıyla oluşturulmuştur. Toprak erodibilite faktörü $(\mathrm{K})$ çalışma alanından alınan toprak örnekleri ve tersinir ağırlıklı ortalama tekniğiyle belirlenmiştir. Eğim uzunluğu ve eğim derecesi faktörü (LS) sayısal arazi yükseklik modelinden yararlanılarak ve bitki amenajman faktörü (C) uydu görüntüleri kullanılarak elde edilmiştir. Belirlenen faktörlere ait haritalar oluşturulmuştur. Elde edilen haritalardan yararlanarak Coğrafi Bilgi Sistemleri (CBS) yardımıyla map algebra modülü raster calculater komutu kullanılarak araştırma alanına ait erozyon miktarı belirlenmiştir. Erozyon miktarı 5 sınıfa bölünmüş ve erozyon risk haritası oluşturulmuştur. Elde edilen potansiyel erozyon risk haritasına göre, araştırma alanının \%60.35'inde çok hafif, \%2.60'ında hafif, $\% 6.08$ ' inde orta, \%10.37'sinde şiddetli ve \%20.60'ında çok şiddetli erozyon görülmektedir.

Anahtar Kelimeler: RUSLE, toprak erozyonu, cbs, uzaktan algılama teknikleri

\section{Introduction}

Soil is one of the major sources in human life, which is formed as a result of long-term interaction between main rock and environment (Blanco and Lal, 2008). According to studies, 200-1000 years are required for forming topsoil with $2.5 \mathrm{~cm}$ thickness under optimum conditions that protective vegetation is also available (Bennet, 1939; Blair, 1942).

Erosion is one of the most important environmental problems in many countries like Turkey (Cangir et al., 2000). Due to water and wind erosions $20 \%$ of top soil is subject to medium soil erosion, while $36 \%$ and $22 \%$ of the topsoil are exposed to high and very high soil erosion respectively in Turkey (AGM, 2008). Annual soil loss in Turkey is about 500 billion ton including 9 billion ton nutrient (Kantarc1, 1980). This process leads to ecosystem and water pollutions also.

Different methods such as RUSLE (Revised Universal Soil Loss Equation) (Wischmeier, 1976), EPIC (Erosion Productivity Impact Calculator) (Yüksel et al., 2007), ANSWERS (Areal Nonpoint Source Watershed Environment Response Simulation) (Beasley et al., 1980), WEPP (Water Erosion Prediction Project) (Okatan et al., 2007), and CORINE (COoRdination of 
Information on the Environmet) (CORINE, 1992; Bayramin et al., 2003) were developed to determine soil loss amount by erosion, sediment productivity, runoff and erosion risk.

RUSLE is an empirical method predicting annual soil loss amount per unit area by considering factors such as climate, soil type, land use and topography impacting erosion (Renard et al., 1997; Covert, 2003; Yüksel et al., 2007).

Erosion risk is predicted by combining RUSLE, remote sensing (RS) and geographic information system (GIS) in grid scale (Milward and Mersey, 1999; Wang et al., 2003). RUSLE method was selected due to easy acquirable data set, compatible with GIS, easy applicable and understandable (Milward and Mersy, 1999).

The aim of this study carried out in Halfal1 stream catchment of Kahramanmaras province is to determine soil erosion risk by using RUSLE method. In accordance with this purpose erodibility, effect of climate on erosion, slope, vegetation, rainfall and topography factors were separately investigated, and then maps were generated by using RS and GIS techniques for each factor. Consequently, erosion risk map was produced by using each factor map according to RUSLE method.

\section{Material and Method}

\section{Study area}

Halfalı stream catchment consists of forest, agricultural and rangeland areas of the mountain Ahir region which is $25 \mathrm{~km}$ away from Kahramanmaras province located in East Mediterranean Region of Turkey. The catchment is located in $37^{\circ} 43^{\prime}$ ' 92"- $37^{\circ} 39^{\prime} 20^{\prime \prime}$ north latitude and $36^{\circ} 57^{\prime} 81^{\prime \prime}-36^{\circ} 59^{\prime} 47^{\prime \prime}$ east longitude (figure 1). Total study area is 1411 ha. The highest point in the catchment is Yamac1 hill with $2053 \mathrm{~m}$, whereas the lowest elevation point is $665 \mathrm{~m}$ near the Menzelet dam.
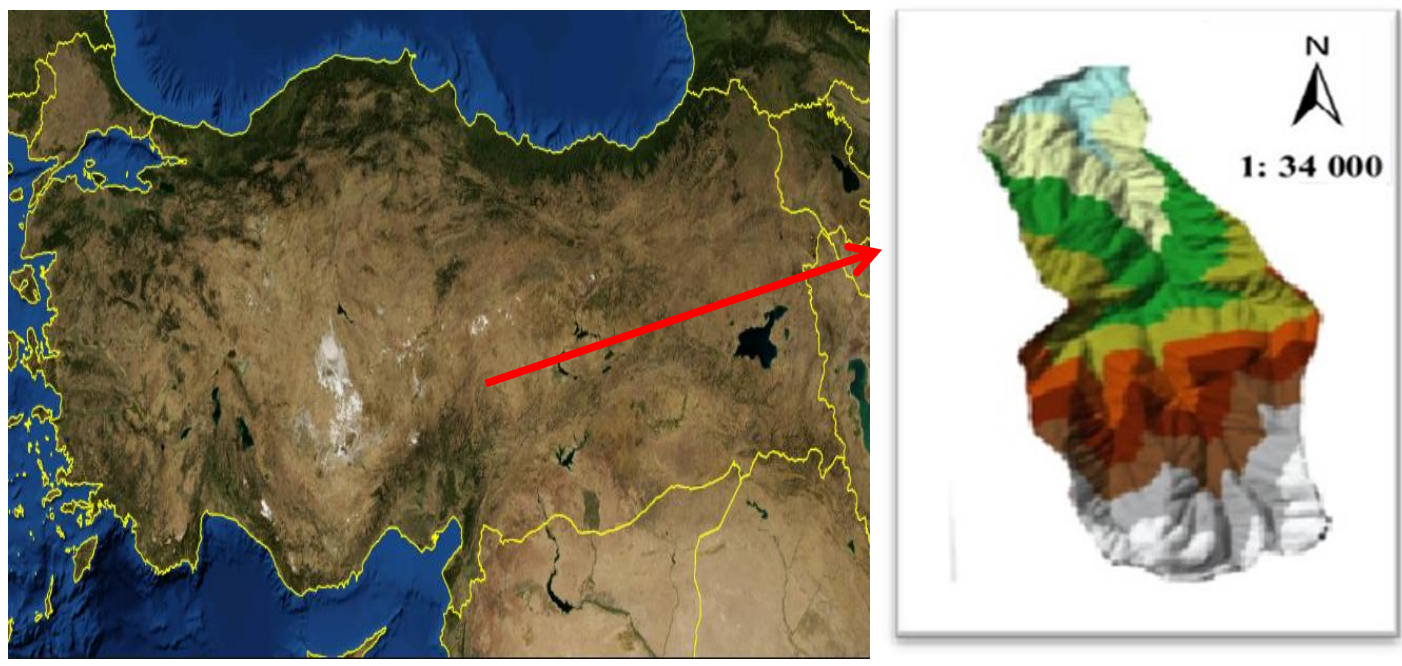

Figure 1. Location of study area in Turkey map and digital elevation model

Study area has Mediterranean climate characteristics, and annual average precipitation amount is slightly over 700 $\mathrm{mm}$. Precipitation generally falls in winter and spring seasons. Annual average temperature is $16.7{ }^{0} \mathrm{C}$. Maximum temperature is $45.2{ }^{0} \mathrm{C}$ (July), while minimum temperature is $-9.6{ }^{\circ} \mathrm{C}$ (February) (DMI 2015). Study area is located in Mediterranean flora zone of Turkey.

\section{Method}

This study was conducted to produce erosion risk map of Halfalı stream catchment using RUSLE method by integrating RS and GIS techniques. In order to determine soil loss by RUSLE method, equation 1 is used.

$$
\mathrm{A}=\mathrm{R} \times \mathrm{K} \times \mathrm{LS} \times \mathrm{C} \times \mathrm{P}
$$

Where; 
A : Annual average soil loss per unit area (ton/ha/year).

$\mathrm{R}$ : Rainfall erosivity factor

$\mathrm{K}$ : Soil erodibility factor

$\mathrm{L}$ : Slope length factor

$S$ : Slope steepness factor

$\mathrm{C}$ : Cover and management factor

$\mathrm{P}$ : Support practice factor

Rainfall erosivity factor $(\mathrm{R})$ is defined as the aggressiveness of the rain to cause erosion (Lal, 1990). It consists of two factors such as kinetic energy and maximum $30 \mathrm{~min}$ intensity of rainfall. If long term pluviograph data are not readily available, it can be calculated using Modified Fournier Index (MFI). (Stocking and Elwell 1976; Arnoldus 1977 and 1980; Roose 1977; Renard and Freimund 1994; Yu and Rosewell 1996c; Lu and $\mathrm{Yu}$ 2002; İrvem et al. 2007). In this study, we used MFI (equation 2) in which annual and monthly average rainfalls were taken into consideration (Arnoldus, 1977).

$$
\mathrm{MFI}=\Sigma \mathrm{pi}^{2} / \mathrm{Pj}
$$

Where; pi is monthly average rainfall $(\mathrm{mm}), \mathrm{Pj}$ is annual average rainfall $(\mathrm{mm})$.

Then, rainfall erosivity factor was determined by using equation 3 (Curebal and Ekinci, 2006).

$$
" \mathrm{R}=(4.17 \mathrm{MFI})-152 "
$$

Data belonging to $1970-2011$ period obtained from Kahramanmaras meteorological station whose elevation is $570 \mathrm{~m}$ was used in order to calculate $\mathrm{R}$ factor.

Soil erodibility factor $(\mathrm{K})$ was obtained using nomograph developed by Wishmeier and Smith (1978). Inverse distance weighted (IDW) which is one of the interpolation methods in ArcGIS was used to map K factor (Anonymous, 1997).

Slope factor in RUSLE represents topographical factors such as slope length (L) and slope steepness (S). Flow chart used to determine LS factor in GIS was introduced in figure 2 .

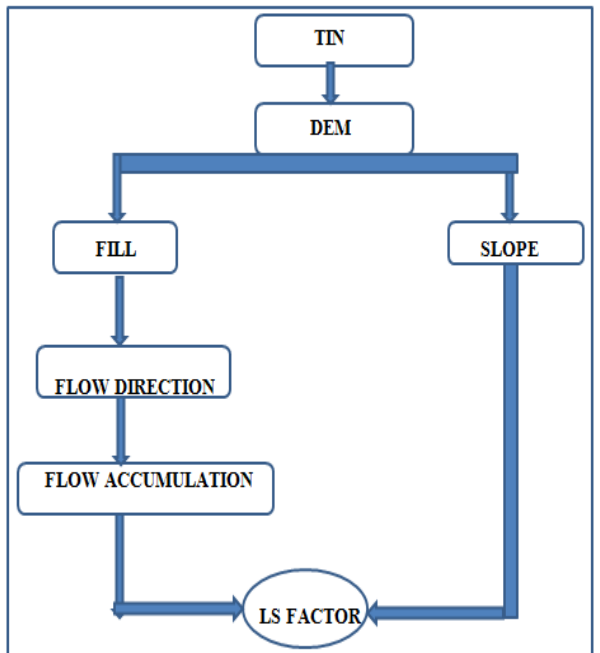

Figure 2. Flow chart for LS factor

Processes in figure 2 were performed using "spatial analysis $>$ map algebra $>$ raster calculator" command in ArcGIS 10.0. Equation 4 suggested by Moore and Burch (1986) was used to calculate LS factor.

LS $=$ (Flow accumulation*Cell size /22.13)^ $0.4^{*}(\sin$ Slope / 0.0896)^1.3) (4)

Cover and management factor (C) represents the effects of vegetation and management on erosion (Renard et al., 1997). C value was determined based on land use types. In order to determine $\mathrm{C}$ factor, supervised classification method in ERDAS 9.1 software was used to produce actual land use map. With this purpose, 10 August 2010 dated Landsat TM satellite image was used for this classification. Study area was divided into 5 classes such as degraded forest, productive forest, poor rangeland, fair rangeland and agriculture. $\mathrm{C}$ values for each land use were presented in table 1. Support practice factor $(\mathrm{P})$ in RUSLE represents soil management practices. Support practice factor was acknowledged as 1, because any soil protection measure was not taken in the study area (Wischmeier, 1975; Wischmeier and Smith, 1978). 
Table 1. Land use type and crop management

\begin{tabular}{cc}
\hline Land use & C value \\
\hline Agriculture & 0.38 (Dept. of. Ag., 2010) \\
\hline Degraded forest lands & 0.42 (Dept. of. Ag., 2010) \\
\hline Productive Forest & 0.39 (Dept. of. Ag., 2010) \\
\hline Poor Rangeland & 0.36 (Goldman et al., 1986) \\
\hline Fair Rangeland & 0.26 (Goldman et al., 1986)
\end{tabular}

Annual soil loss was calculated by using rain erosivity, erodibility, slope length and steepness, cover and management and support practice factor maps. Calculation process was performed by using raster calculator command of map algebra under spatial analysis tool in Arc map 10.0. As a result, soil erosion risk map was produced based on soil loss. Morgan (1995) reported that tolerable soil loss was 10 ton/ha/year for agricultural production. This limit value was taken into consideration in classification of soil loss ratio in this study.

\section{Results and Discussion}

$R$ values obtained in the study area were presented in figure 3 and table 2. Areas having higher $\mathrm{R}$ values had higher elevation. It can be said that this relationship is normal, as rainfall increases based on elevation increase.

Climate parameters such as precipitation, temperature and wind have an important impact on runoff and erosion. Among these parameters, precipitation has major effect on erosion (Dogan and Gucer, 1976; Ozturk, 1995). Areas with higher $R$ values in the study area were located in areas with higher elevation. Dogan (2002) calculated R values of 96 stations in Turkey by investigating long-term data of these stations. According to results, areas with higher $\mathrm{R}$ values were areas where precipitation amount was higher, and precipitation type was rainfall generally. Rize and Marmaris stations had the highest $\mathrm{R}$ values by 481 and 522 respectively, while Aksaray and Van had the lowest $R$ values by 122 and 362 respectively.

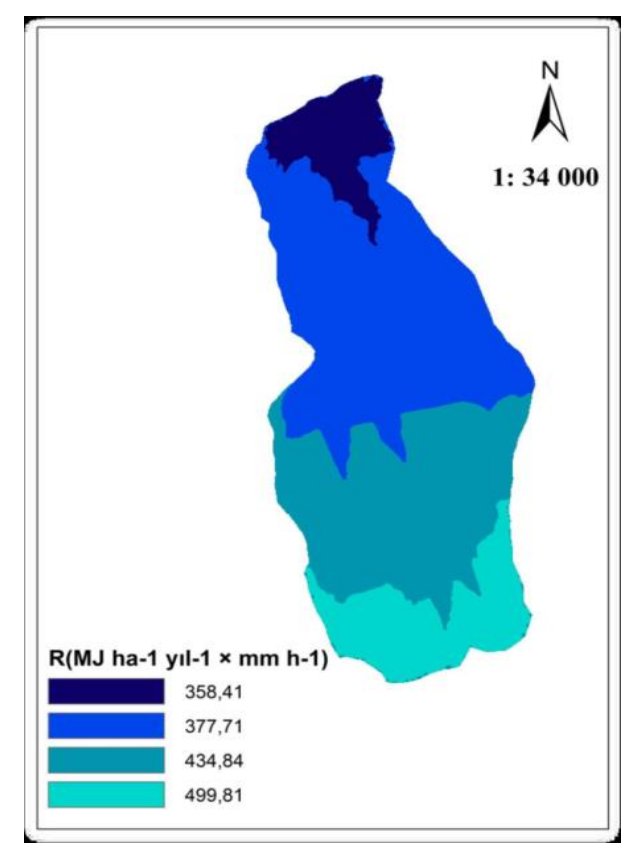

Figure 3. Spatial distributions of rainfall erosivity index

Table 2. MFI and R values based on elevation group

\begin{tabular}{ccc}
\hline Elevation $(\mathrm{m})$ & MFI & $\mathrm{R}$ \\
\hline $0-650$ & 122.4 & 354.408 \\
\hline $650-1100$ & 127.03 & 377.715 \\
\hline $1100-1600$ & 140.03 & 438.844 \\
\hline $1600-2100$ & 156.31 & 499.813 \\
\hline
\end{tabular}


In this study, it was found that $4 \%(56.39$ ha) of the study area was subject to very resistant class, while, $17 \%$ (253.35 ha) and $3.27 \%$ (46.22 ha) of the study area were subject to erodible and very erodible classes respectively in terms of $\mathrm{K}$ factor (Figure 4 and Table 3).

According to $\mathrm{K}$ factor map, values range from 0.01 to 0.6 . $\mathrm{K}$ values were higher in agricultural and rangeland soils, while forest soils have the lowest $\mathrm{K}$ values in study area. Similarly, Sujaul et al. (2012) reported that K values ranged from 0.03 to 0.3 in their study area in Malaysia. Soils in the study area had weak structure and low organic matter content (\%1.64) due to high average sand and silt ratio (\% 81), and so they were susceptible to erosion.

Table 3. Areal and proportional distribution of erodibility

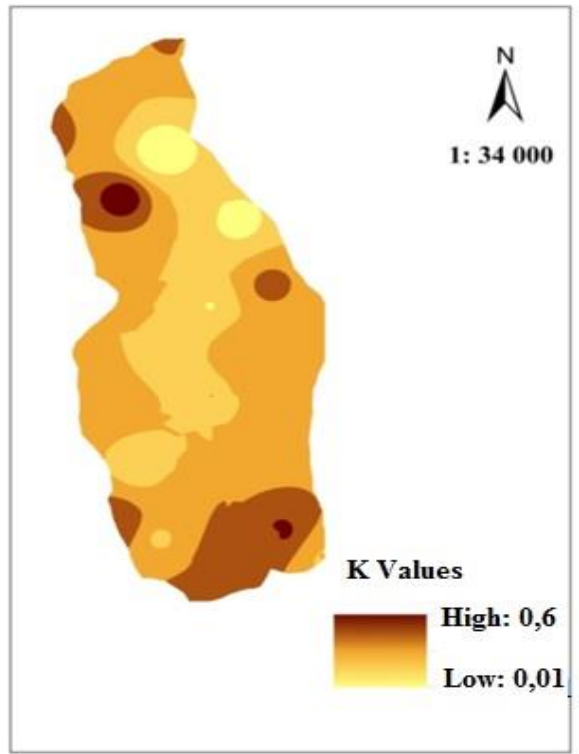

Figure 4. Spatial distribution of soil erodibility factor

\begin{tabular}{ccrc}
\hline Soil Erodibility Factor & Erodibility Definiton & Area (Ha) & \multicolumn{1}{c}{ Ratio (\%) } \\
\hline $0.00-0.05$ & Very Resistant & 56.39 & 4 \\
\hline $0.05-0.10$ & Resistant & 382.2 & 27.08 \\
\hline $0.10-0.20$ & Moderately Resistant & 673.14 & 47.7 \\
\hline $0.20-0.40$ & Erodible & 253.35 & 17.95 \\
\hline $0.40-0.60$ & Very Erodible & 46.22 & 3.27 \\
\hline
\end{tabular}

Giordani and Zanchi (1995) revealed that loamy soils having higher silt and fine sand content had lower permeability and durability against transportation. Wawer et al. (2005) and Zhang et al. (2007) indicate that low clay and high sand content in soils gave rise to increase $\mathrm{K}$ factor. In addition to these studies, Charman and Murphy (1991), Bal (1990) stated that organic matter made soils enduring against erosion due to its cement effect.

High LS values in the study area were seen in areas where slope was higher, stream network was more density, and were generally located in north of the study area (Figure 5). Runoff amount in the study area increased due to low density vegetation

and absence of soil and water protection measures. So, this situation caused higher LS values. Celik (2011) determined that LS had higher effect on erosion than other factors, higher slope areas had higher erosion risk, and so $30 \%$ of his study area was subject to high and very high erosion risk in his master thesis.
According to data obtained from slope map, approximately $68 \%$ of the Halfal stream catchment was involved in steep and very steep classes (Table 4).

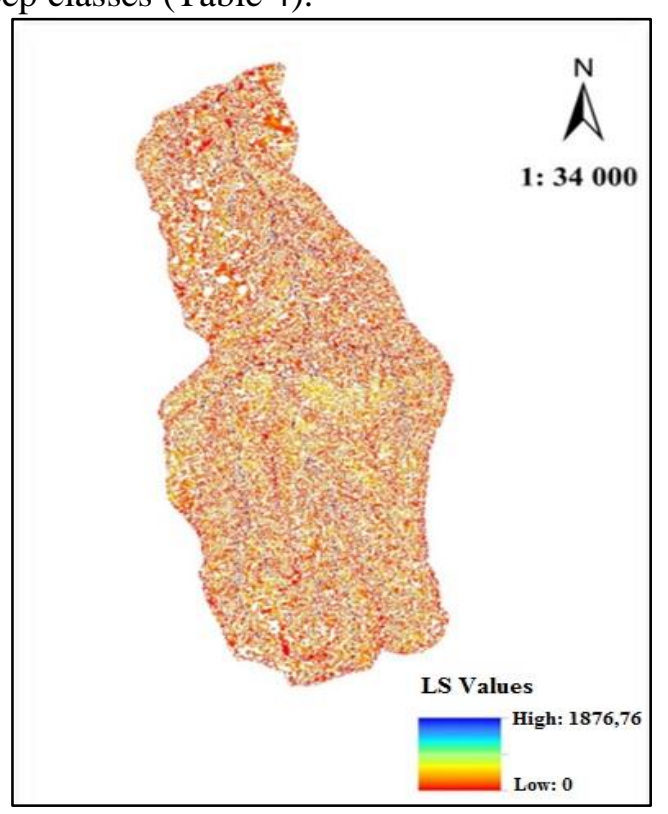

Figure 5. Spatial distribution of slope length and steepness factor 
Table 4. Areal and proportional distribution of slope classes

\begin{tabular}{ccc}
\hline Slope classes & $\begin{array}{c}\text { Area } \\
\text { (ha) }\end{array}$ & $\begin{array}{c}\text { Ratio } \\
(\%)\end{array}$ \\
\hline $0-2$ (Flat) & 14.16 & 1.00 \\
\hline $2-6$ (Low) & 16.36 & 1.16 \\
\hline $6-12$ (Medium) & 92.86 & 6.58 \\
\hline $12-20$ (High) & 337.45 & 23.91 \\
\hline $20-30$ (Very high) & 570.27 & 40.41 \\
\hline$>30$ (Steep) & 380.20 & 26.94 \\
\hline Total & 1411.30 & 100 \\
\hline
\end{tabular}

Slope is main factor affecting relationship between runoff and soil loss. In a certain place, when all other factors are equal, erosion is higher in areas having higher slope due to higher runoff (Ekinci, 2005). As noted by Biricik (1985), if hill slope exceeds over 20\%, runoff accelerates, and erosion increases. Increase in slope value influences erosion not only by accelerating runoff but also by increasing impact force of raindrop (Sonmez, 2010).

According to results obtained from actual land use map, $21.74 \%$ (306.85 ha) of the study area was poor rangeland, while $17.21 \%$ (241.56 ha), $27.44 \%$ (387.21 ha), $8.48 \%$ (119.63 ha) and $25.22 \%$ (356.05 ha) of the study area were fair rangeland, agricultural, degraded forest and productive forest respectively.

Crop management factor map was presented in figure 6 . One of the main reasons of soil loss in the catchment was improper land use. In addition to this, the catchment generally had V., VI. and VII. land capability classes due to high average slope, and major part of vegetation consisted of rangeland and forest areas with low density. These conditions in the study area cause to increase erosion.

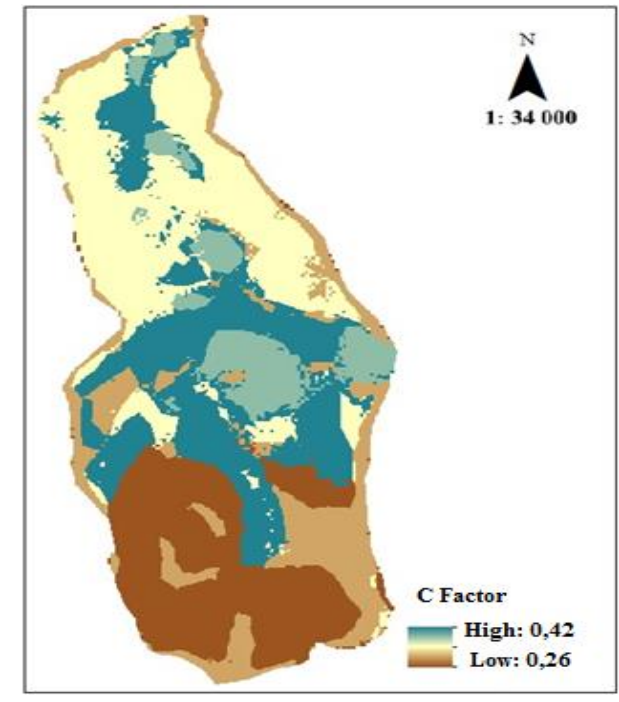

Figure 6. Crop management factor

Crop management factor varied from 0.26 to 0.42 in the study area. In areas with higher erosion risk, it was determined that slope was higher, vegetation was sparse, drainage density was higher, and erodibility was higher. On the other hand, it was seen that erosion was lowest in forest areas. In this study, strong relationship between vegetation distribution and erosion severity was also determined. In areas with higher vegetation density, erosion risk was lower in spite of higher slope. On the contrary, in areas with lower slope erosion risk was higher due to sparse vegetation or nonvegetation. Filho and Neto (1995) stated that vegetation was major factor affecting erosion. Vegetation protects soil against erosion by decreasing raindrop effect, runoff and wind speed (Cepel, 1997). Moreover, vegetation decreases runoff by interception (Cepel, 1997; Altın, 2006). As vegetation ratio covering soil 
increases, soil susceptibility to erosion decreases (Zachar, 1982).

According to NDVI map, vegetation density was generally low $(<25 \%)$ in the study area (figure 7). Low vegetation density in the catchment gave rise to increase both erosion and also erosion risk. According to erosion risk map of study area, in areas with severity and very severity erosion, vegetation density was lower. As noted by Wal (2003) potential erosion is higher in areas having sparse vegetation.

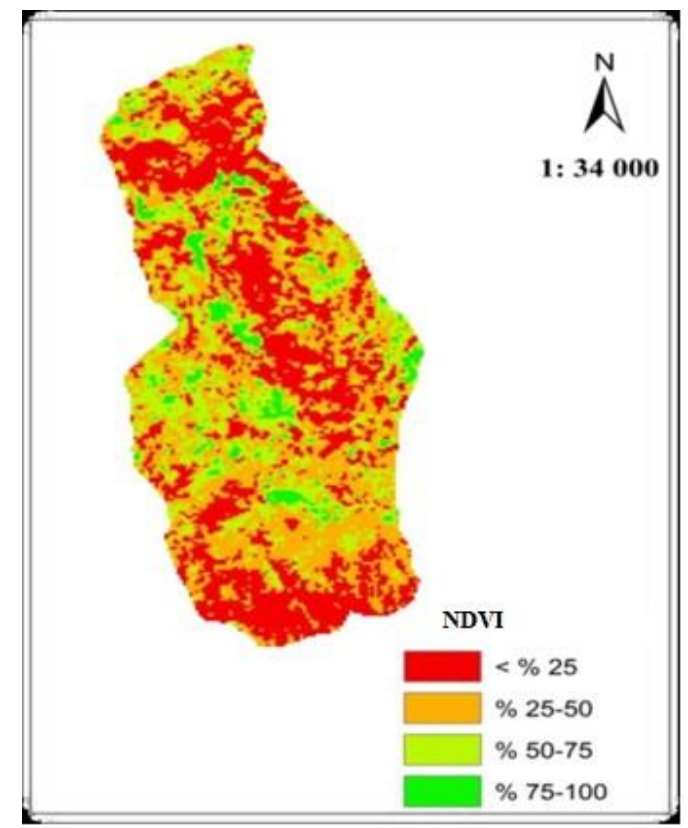

Figure 7. Vegetation density map

In a study conducted in Queensland in Australia by Loch (2000) showed that erosion amount decreased from 30-35 ton/ha to 0.5 ton/ha, as vegetation density increased from $0 \%$ to $47 \%$ respectively. In an another study performed under natural rainfall condition, total 9.4 ton/ha soil loss occurred on soil surface protected by vegetation in 10 years, whereas total 1265.7 ton/ha soil was lost on no protected soil surface in 10 years. When these two cases were compared, soil loss amount on no protected surface were more than the other about 135 times (Taysun, 1989). This study clearly indicated the importance of vegetation.

Areal and proportional distributions of erosion risk classes obtained from erosion risk map of Halfalı stream catchment were introduced in figures 8 and 9. Potential erosion risk was divided into 5 classes in the catchment. It was determined that $60.35 \%$ of the catchment was subject to very low erosion risk, while $2,60 \%, 6.08 \%, 10,37 \%$ and $20.60 \%$ of the catchment was subject to low, moderate, high and very high erosion risk respectively (Figure 9).

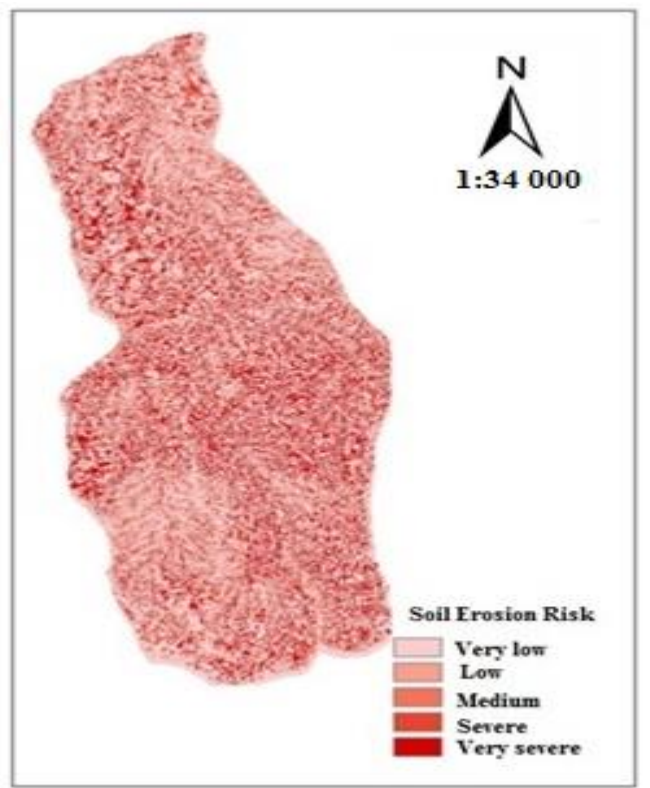

Figure 8. Erosion risk map of study area

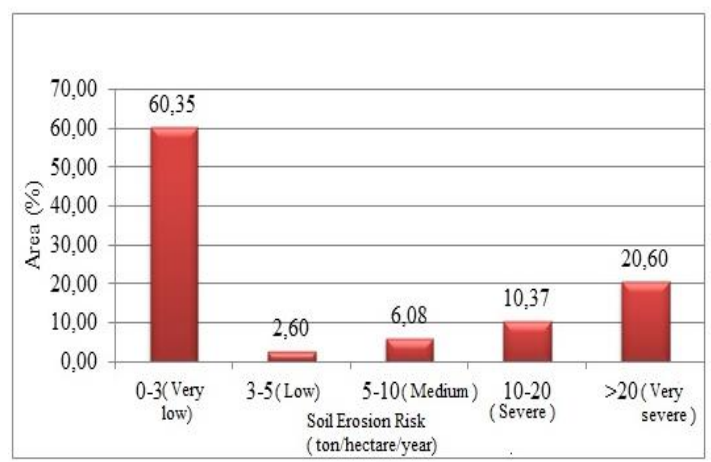

Figure 9. Distribution of erosion risk classes

The second value was over Turkey average (6.14 ton/ha/year) reported by Cakal et al. (1997). However, it was very close to soil loss value (11.18 ton/ha/year) of Bursa Mustafa Kemal Pasa watershed calculated by Ozsoy (2007). In addition, this value was about 2 times less than value (28.85 ton/ha/year) calculated by Tombus et al. (2012) using the same method in Corum province. It was thought that this difference resulted from differences between in natural and human environmental components of the two areas. In a similar way, Taysun et al. (1995) also stated that differences in natural factors, land use and 
socioeconomic factors caused different impact on erosion severity.

In studies relation to erosion, similar results were reached, and it was indicated that approximately $90 \%$ of turkey soil was exposed to erosion (Karaburun et al., 2009). Savac1 (2012) determined potential erosion risk of Goz and Haman stream watersheds by using CORINE method in Kahramanmaras province. According to results of abovementioned study, areas whose erosion risk was 0-5\% constituted $70.17 \%$ of total area, while areas whose erosion risk was $5-11 \%$ and more than $11 \%$ constituted $15.86 \%$ and $13.97 \%$ of total area respectively in Goz watershed. In Haman watershed, areas whose erosion risk was $0-5 \%$ and more than $11 \%$ constituted $70.83 \%$ and $29.17 \%$ of total area respectively.

Renald et al. (1997) stated that climate (R factor) and soil properties ( $\mathrm{K}$ factor) were unrestrainable and noncontrolable stable factors. Therefore, soil conservation practices should be aimed for land use and vegetation (C factor), topographical factors (LS factor) and soil tillage systems (P factor). In this respect, land use and vegetation practices ( $\mathrm{C}$ factor) become the most important factors in soil conservation. When land use and vegetation density map were investigated, it was seen that there is less area with high vegetation density, and $33.7 \%$ of the study area was covered by sparse forest areas. So, the most important measure which can be taken against erosion in Halfal 1 stream catchment is to increase vegetation density, and to observe land capability classes.

Soil erosion is an important problem in Halfalı stream catchment. Improper land use is the most important reason of this condition. So, areas in the catchment should be used according to land capability, and improper land use was immediately discontinued. Otherwise, soils will become infertile to meet the human needs due to potential erosion in the catchment. Consequently, land capability classes must be determined, and slope improvement measurements must be urgently taken in the catchment.

\section{References}

AGM, 2008. Ağaçlandırma ve erozyon kontrolü genel müdürlüğü, URL (erişim tarihi: 08.01.2011) http://www.agm.gov.tr.
Altın, M. 2006. Erozyon, doğa ve çevre, TEMA vakfı yayınları, (mera-erozyon ilişkileri, Ed: Ahmet Aydemir), İstanbul.

Anonymous, 1997. Understanding GIS, The ARC/ INFO method. environmental systems research institute, inc. Distributed in the Americas by John Willey \& Sons, Inc. 605 Third Avenue, New York, USA.

Arnoldus, H.M. J. 1977. Methodology used to determine the maximum potential average soil loss due to sheet and rill erosion in Morocco, Assessing Soil Degradation, FAO Soils Bulletin, 34, 8-9.

Arnoldus, H.M.J. 1980. An approximation of the rainfall factor in the universal soil loss equation. In: M. De Boodt and D. Gabriels (Editors), Assessment of Erosion. J.Wiley and Sons, Chichester, 127-132 s. England.

Bal, A. 1990. Soil properties and their uses. John Wiley and Sons. London. Balc1, A.N., Erodobility Characteristics of Some Forest Soils Developed Under the Influence of Arid and Humid Climatic Conditions, İ.Ü.Ö.F Yayınları, İ.Ü. Yayın No: 2402, İ.Ü. Orman Fakültesi Dergisi, B, 21, 1 (1971), 48-58.

Bayramin, İ., Dengiz, O., Baskan, O., Parlak M. 2003. Soil erosion risk assessment with ICONA Model; Case Study: Beypazarı Area, Turk Journal Agriculture Forestry 23, 105-116.

Beasley, D.B., Huggins, L.F., Monke, E.J. 1980. Answers: A model for watershed planning, Trans. of the ASAE 23 (4), 938-944s.Corine, 1992. Soil erosion risk and important land resources in the southern regions of the European Community. EUR 13233, Luxembourg.

Covert, A. 2003. Accuracy assessment of WEPP-based erosion models on three smal, harvested and burned forest watersheds. MSc Thesis, Natural Resource College of University of Idaho, USA.

Cürebal, İ., Ekinci, D. 2006. Kızılkeçili deresi havzasında CBS tabanlı RUSLE -yöntemiyle erozyon analizi, Türk Coğrafya Dergisi, 47, 115130.

Çakal, M.A., Özlü, A., Birhan, H., Bakır, H., Gültepe, N.Z., Ayday, C. 1997. Tortum gölü havzasının uzaktan algılama ve coğrafi bilgi sistemiyle erozyon risk haritasının hazırlanması. Türkiye'nin Erozyon Sorunu ve Adana'nın Yeri Kongresi, Çağrılı Bildiriler, Proje Tasarımları, Önlem ve Öneriler Kitabı, 5-6 Aralık 1997, Adana.

Çelik, V. 2011. Değirmen deresi havzasında (Bolvadin-Afyonkarahisar) toprak erozyonu risk analizi. Yüksek Lisans Tezi. Afyon Kocatepe Üniversitesi, Sosyal Bilimler Enstitüsü, Afyonkarahisar.

Çepel, N. 1997. Toprak kirliliği erozyon ve çevreye verdiği zararlar, Tema Vakfı Yayınları 14, İstanbul. 
Doğan, O. ve C. Güçer. 1976. Su erozyonunun nedenleri, oluşumu ve üniversal denklem ile toprak kayıplarının saptanması. T.C. Köy İşleri Bak. TOPRAKSU Genel Müd. TOPRAKSU Araş. Enst. Müd. Yay. No.41. Ankara. 159s.

Doğan, O. 2002. Türkiye yağışlarının erozyon oluşturma gücü ve universal toprak kaybı eşitliğinin yağış erozyon indeks değerleri. KHGM, Ankara Araş. Enst. Müd. Yay. Genel Yay. No:220, Rapor Yay. No:R-120, Ankara. 211s.

DMI, 2015. Devlet meteoroloji işleri Gn. Md., K.Maraş Meteoroloji İl Müdürlüğü, K.Maraş Meteoroloji İstasyonu Verileri, 1975-2015. Kahramanmaraş.

Anonymous, 2010. Urban stormwater management manual for Malaysia, Chapter 13 Design Rainfall.

Ekinci, D. 2005. CBS tabanlı uyarlanmış RUSLE yöntemi ile kozlu deresi havzası'nda erozyon analizi. İstanbul Üniversitesi Edebiyat Fakültesi Coğrafya Bölümü Coğrafya Dergisi, 13, 109-119.

Filho, M. V., O. C. Neto, 1995. Geoprocessing tecniques applied to the study of the dynamics of land use and land cover at smal watersheds. International Geoscience and Remote Sensing Symposium. v. 1,95CH35770, p.297-299. Giordani, C., and Zanchi, C., 1995: Fundamentals of Soil Conservation. Bologna, Patron. 220 (In Italian).

Goldman, S.J., Jackson, K, Bursztynsky, T. A. 1986. Erosion and Sediment Control Handbook. Chapter 4.

İrvem, A., Topaloğlu, F. and Uygur, V. 2007. Estimating spatial distribution of soil loss over Seyhan River Basin in Turkey. Journal of Hydrology 336, 30-37.

Kantarc1 M.D. 1980.The research on distinguishing and mapping of forest site unity and soil types in Belgrade forest. Istanbul University Faculty of Forestry publication No:2636, Istanbul, Turkey (in Turkish).

Karaburun, A., Demirci, A. ve Karakuyu, M. 2009. Erozyon tahmininde CBS tabanlı rusle metodunun kullanılması: büyükçekmece örneği, 3 . Dokuz Eylül Üniversitesi CBS Sempozyumu CBS ve Bilgi Teknolojileri 10-11 Aralık, İstanbul.

Lal, R. 1990.Soil erosion in the tropics: principles and management. McGraw-Hill, New York.

Loch, R.J. 2000. Effects of vegetation cover on runoff and erosion under simulated rain and overland flow on a rehabilitated site on the Meandu Mine, Tarong, Australian Journal of Soil Research 2000 Vol. 38 No. 2, 299-312

Lu, H., Yu, B. 2002. Spatial and seasonal distribution of rainfall erosivity in australia.
Australian Journal of Soil Research, 40(6), 887901.

Millward, A.A and Mersey, J.E. 1999. Adapting the RUSLE to model soil erosion potential in a mountainous tropical watershed, Catena, 38,109129.

Moore, I.D and Burch, G.J. 1986. Physical basis of the length-slope factor in the universal soil loss equation. Soil Science Society of America Journal, 50, 1294-1298.

Morgan, R.P. 1995. Soil Erosion and conservation, second edit. Longman Group, Cranfield, s. 412.

Okatan, A., Aydın, M. ve Urhan O. Ş. 2007. Coğrafi bilgi sistemlerinin havza amenajmanında kullanımı ve önemi, TMMOB Harita ve Kadastro Mühendisleri Odası Ulusal Coğrafi Bilgi Sistemleri Kongresi 30 Ekim- 02 Kasım, Trabzon.

Özsoy, G. 2007. Uzaktan alg1lama (UA) ve coğrafi bilgi sistemi kullanarak (CBS) erozyon riskinin belirlenmesi. Doktora Tezi. Uludağ Üniversitesi. Fen Bilimleri Enstitüsü. 140s. Bursa.

Öztürk, N. 1995. Coğrafi bilgi sistemi (GIS) ve sayısal uydu verilerinin detaylı toprak etüdlerinde kullanma olanakları. Doktora Tezi. Çukurova Üniversitesi Fen Bilimleri Enstitüsü. Toprak Anabilim Dalı, Adana. 106s.

Renard, K.G and Freimund, J.R. 1994. Using monthly precipitation data to estimate the $r$-factor in the revised USLE. Journal of Hydrology, 157, 287306.

Renard, K.G., Foster, G.R., Weesies, G.A., McCool, D.K and Yoder, D.C. 1997. Predicting soil erosion by water: a guide to conservation planning with the revised universal soil loss equation (RUSLE). Agriculture Handbook No.703, USDA, Washington, DC.

Roose, E. 1977. Erosion and runoff in West Africa from 20 Years of Records for Smal Experimental Plots. Works and Documents of OSTROM, No:78, Paris.

Savac1, G. 2012. Kahramanmaraş ili göz ve haman deresi yağış havzalarında CORINE metodolojisi ile erozyon risk haritalarının oluşturulması. Yüksek Lisans Tezi. Kahramanmaraş Sütçü İmam Üniversitesi, Fen Bilimleri Enstitüsü. 154s. Kahramanmaraş.

Sönmez, K. 1994. Toprak koruma ders kitabı. Atatürk Üniv. Ziraat Fak. Yayınları. No: 169, Erzurum, s.192.

Sönmez, E. 2010. Mekânsal Potansiyel ve Kalkınmayı Geciktiren Sorunlara Coğrafi Bir Yaklaşım: Göksu Çayı Havzası (Adıyaman), Basılmamış Doktora Tezi, İstanbul Üniversitesi. Sosyal Bilimler Enstitüsü. İstanbul.

Stockıng, M.A and Elwell, H.A. 1976. Rainfall erosivity over rhodesia. Trans. Of the Inst. Of British Geographers, New Series, 1(2), s.231-245. 
Sujaul, I.M., Muhammad Barzani, G., Ismail, B.S., Sahibin, A.R., Mohd Ekhwan, T. 2012. Estimation of the rate of soil erosion in the Tasik Chini Catchment, Malaysia using the RUSLE Model Integrated with the GIS Australian Journal of Basic and Applied Sciences, 6(12), 286-296.

Taysun, A. 1989. Toprak ve su korunumu. E.Ü. Zir. Fak. Ders Teksiri No: 92- III.Bornova, İzmir. 72 s.

Tombuş, F.E., Yüksel, M., Şahin, M., Ozulu, İ. M., Coşar, M. 2012. Assessment Of soil erosion based on the method USLE; Çorum Province Example. FIG Working Week 2012 Knowing to manage the territory, protect the environment, evaluate the cultural heritage Rome, 6-10 May 2012, 1-11, Italy

Wal, O.S.G. 2003. Soil Erosion-Causes and Effects.

Wischmeier, W.H. 1976. The use and misuse of the universal soil loss equation. Journal of Soil and Water Conservation, 31 (1), 5-9.

Wang, G., Gertner, G., Fang, S., Anderson, A.B. 2003. Mapping multiple variables for predicting soil loss by geostatistical methods with tm images and a slope map. photogrammetric, Engineering and Remote Sensing 69, s.889-898.

Wawer, R., Nowocien, E., Podolski, B. 2005. Real calculated k- usle erodobility factor for selected polish soils. Polish J.Environ. Stud. 14 (5):665-658

Wischmeier, W.H. 1975. Estimating the soil loss equations cover and management factor for undisturbed lands. In Present and Prospective Technology for Predicting Sediment Yields and Sources. U.S. Dep. Agric., Agric. Res. Serv., ARSS-40. s.118-125.

Wischmeier, W.H., Smith, D.D. 1978. Predicting rainfall erosion losses: a guide to onservation planning, agricultural handbook, US Department of Agriculture, Washington, DC, USA s. 537.

Yüksel, A., Akay, A.E., Reis, M., Gundogan, R. 2007. Using the WEPP model to predict sediment yield in a sample, watershed in Kahramanmaras Region. International Congress River Basin Management, 2, 11-22, Antalya.

$\mathrm{Yu}, \mathrm{B}$ and Rosewell, C.J. 1996. A robust estimator of the r-factor for the universal soil loss equation. Trans. Am. Soc. Agric. Eng., 39:559-561.

Zachar, D. 1982. Soil erosion, Elsevier Scientific Publishing Company, USA.

Zhang, Z.G., Fan, B.E., Bai, W.J., Jiao, J.Y. 2007. Soil anti-erodobility of plant communities on the removal lnds in hilly-gully region of the loess plateau. Science Soil Water Conser. 5:s. 7-13. 